\title{
Legal Positivism and the Moral Origins of Legal Systems
}

\author{
Emad H. Atiq \\ Cornell Law School \& the Sage School of Philosophy, Ithaca, NY, USA
}

\begin{abstract}
Legal positivists maintain that the legality of a rule is fundamentally determined by social facts. Yet for much of legal history, ordinary officials used legal terminology in ways that seem inconsistent with positivism. Judges regularly cited, analyzed, and predicated their decisions on the 'laws of justice,' which they claimed had universal legal import. This practice, though well-documented by historians, has received surprisingly little philosophical attention; I argue that it invites explanation from positivists. After taxonomizing the positivist's explanatory options, I suggest that the most viable option appeals to conceptual change: classical Romans, early modern Europeans, and founding-era Americans were not using 'law' (or 'lex' or ' $j u s$ ') to refer to the subject matter of contemporary legal philosophy. But the strategy is costly. It renders positivism's truth surprisingly parochial. And it supplies new reasons for doubting positivist accounts of contemporary practices, including the treatment of moral principles in modern adjudication.
\end{abstract}

Key Words: Concept of law; Jus Naturale; Moral principles; Legal Positivism; Conceptual genealogy

\section{Introduction}

It is not the job of legal philosophy to bring unity to all recorded uses of 'law.' Nevertheless, a good philosophical account of law should be diachronically plausible. It should be able to make explanatory sense of the history of the concept of juridical law. ${ }^{1}$ This modest point does not rely on the assumption that when we talk about law today, we share an identical concept with our distant linguistic forbears. It assumes only that we have reason to expect some connection between the subject matter of legal philosophy and the use of legal terminology across history.

One way to motivate this connection is by appeal to norms of semantic deference. ${ }^{2}$ Our dispositions to defer to others in our linguistic community play a

1. I echo an observation of Jennings' that a philosophical account of a concept can be evaluated based on its fit and explanatory power in relation to the concept's history; see RE Jennings, The Genealogy of Disjunction (Oxford University Press, 1995). On the use of conceptual genealogy in analytic philosophy, see M Queloz, The Practical Origins of Ideas: Genealogy as Conceptual Reverse-Engineering (Oxford University Press, 2021).

2. On semantic deference, see T Burge, "Intellectual Norms and the Foundations of Mind" (1986) 83:12 J of Philosophy 697; P Horwich, Reflections on Meaning (Oxford University Press, 2005) at 52; L Schroeter \& F Schroeter, "Semantic Deference versus Semantic Coordination" (2016) 53:2 American Philosophy Quarterly 193. 
role in fixing the content of many of our concepts. We defer to natural scientists on the nature of the referent of 'water.' Likewise, we defer to jurists concerning the content of the law. Moreover, our semantic deference practices in the legal case arguably extend into the past, to the origins of legal systems. For example, in the United States, constitutional originalists regard the meaning of legal terminology — and some, the very idea of law itself - as fixed at the founding of the American legal order. The founders in turn borrowed liberally from the English legal tradition, and English jurists had deference dispositions of their own. Given such chains of semantic deference, however varied and potentially unstable, it would be surprising to discover that past legal usage has played no role in determining the content of our prevailing legal concept. ${ }^{3}$

This paper explores the relationship between the historical concept of law as reflected in the use of legal terminology by ordinary legal officials, and legal positivism, widely credited as being the leading theory of law in contemporary analytic jurisprudence. Positivists maintain that social facts-facts concerning what people have said, believed, done, or intended to do-fundamentally determine whether a rule or norm counts as law. On Hart's influential formulation, what makes a rule a 'rule of law' is either the prevalence in the jurisdiction of certain attitudes of obedience towards the rule or the fact that the rule can be derived from more fundamental legal rules that are generally obeyed, for example, rules of adjudication or law-making. ${ }^{4}$ A sampling of the historical record serves to introduce a general puzzle that positivists have overlooked but ought to address. For much of legal history, ordinary officials classified moral principles as law on seemingly a priori grounds, a practice that at least on its surface seems inconsistent with positivism. In addition to relying on principles of fairness, impartiality, and justice in adjudication, ${ }^{5}$ judges regularly attributed a species of universal legality to such principles. These are not just passing references to the 'laws of justice,' as a judge might refer to the 'laws of chess' in a case that happens to implicate some extra-legal normative structure. Rather, 'moral laws' have been used in ways that bear all the markings of juridical law: they have been cited, analyzed, and made the basis for prominent holdings. ${ }^{6}$ And the more deeply

3. As Burge puts it, "[w]e may imagine a vast, ragged network of [semantic] interdependence, established by patterns of deference which lead back to people who would elicit the assent of others." Burge, supra note 2 at 702.

4. See HLA Hart, The Concept of Law, $3 \mathrm{~d}$ ed by Penelope A Bulloch \& Joseph Raz (Clarendon Press, 2012).

5. The fact that modern judges rely on moral principles in adjudication is the locus of a familiar disagreement between Ronald Dworkin and legal positivists. See R Dworkin, "The Model of Rules" (1967) 35:1 U Chicago L Rev 14 [Dworkin, "Model of Rules"]; Ronald M Dworkin "Social Rules and Legal Theory" (1972) 81:5 Yale LJ 855; Ronald Dworkin, "Hard Cases" (1975) 88:6 Harv L Rev 1057. The relevance of genealogical considerations to this disagreement has been overlooked: see $\S 2$.

6. Shapiro reminds us that "many things that English speakers refer to as 'law' are not law in the relevant sense," for example 'Boyle's law' and the 'law of Cosines'; see S Shapiro, Legality (Harvard University Press, 2011) at 8 . I focus on cases where the contextual evidence strongly indicates that references to 'moral law' or the 'law of justice' are intended in the juridical sense - as the law of the land to be applied in cases. We can distinguish legally relevant uses of 'law' by closely examining what jurists say and do, while drawing on relatively uncontested 
we examine the record-from 19th century Anglo-American law to classical Roman law - the more pervasive the practice appears.

Section 1 of this paper summarizes the historical evidence. This initial section moves quickly relative to its scope, since the paper's primary focus is on the record's philosophical significance, and not on providing a comprehensive history of the 'laws of justice.' The purposefully targeted examination is designed to motivate an explanatory puzzle along with the importance of examining this history more closely. Section 2 observes that the historically ordinary-that is, nonphilosophical and relatively mainstream - conception of moral principles as 'natural laws' receives limited attention within the Hart-Dworkin debate, even though central questions in this debate are not entirely unrelated to historical practice.

Next, I argue that the usage facts invite explanation from the positivist, and I proceed to taxonomize the available explanatory strategies. Section 3 considers an initial set of strategies on behalf of the positivist; these proceed on the assumption that we share a common concept of law with the past. The CONVENTIONALIST appeals to positivist criteria for legality to explain why jurists through the ages have classified moral principles as law: a jurisdiction-specific legal custom licensed the classifications. The FICTIONALIST takes the judgments to be insincere, a useful fiction that officials have knowingly indulged in. The ERRORTHEORIST pegs the judgments to a pervasive mistake or confusion. I argue that conventionalism $(\S 3.1)$ and fictionalism $(\S 3.2)$ are not supported by the historical evidence; both interpretations distort the claims and behavior of jurists. Meanwhile, a positivist error-theory $(\S 3.3)$ lacks a plausible theory of error. The problem is that the affirmative claims that make up positivism cannot explain why experts immersed in legal practice would have had basic intuitions about law that are not just mistaken but, on the assumption of positivism, seem implausibly arbitrary. ${ }^{7}$

Since the above strategies for reconciling historical usage with positivism seem weak, Section 4 considers an alternative (and more promising) approach that involves denying the common concept assumption. The REFERENCESHIFTER maintains that the meaning of legal terminology has shifted over time, tracking the evolving dispositions of legal language users. While this approach has several virtues, it is not without cost. For one, it renders the truth of positivism surprisingly parochial in a way that calls into question standard accounts of the philosophical dialectic. On the standard picture, philosophers offering a metaphysics of juridical 'law,' from Aristotle and Aquinas to their contemporary counterparts, have been analyzing a shared subject; reference-shift seems incompatible with this picture. Moreover, the positivist needs an account of conceptual change- how a term with a putatively moral meaning ended up referring to a

assumptions about the theoretical role of the juridical concept. The positivist cannot declare by fiat that a judge's use of 'law' to refer to moral principles is extra-legal, no more than the antipositivist can take for granted that any reference to 'moral law' is relevant to legal philosophy. For further discussion, see $\S 1$.

7. This point is compatible with past jurists being mistaken. The target isn't error theories in general, but an error theory that is specifically based on positivism. For further discussion, see $\S 3.3$. 
subject amenable to positivistic analysis. ${ }^{8}$ And certain ways of developing this meta-semantic account, I argue, reveal new reasons for doubting positivist interpretations of contemporary practices, such as a modern judge's reliance on moral considerations in adjudication.

\section{Genealogical Jurisprudence}

The history of the concept of law and legal usage has yet to be written, and a comprehensive account of this history lies well beyond the scope of this paper. In this section, I limit myself to highlighting one aspect of the historical record to explore its philosophical significance — namely, the basis for thinking that jurists standardly conceived of moral principles as a form of universal law in prior legal systems. I offer a sampling of juridical commentary on the 'law of justice' and accounts of the practice furnished by historians. Invariably, the following observations are informed by assumptions about the legal concept's theoretical rolefor example, that law is used to decide cases, laws are cited, laws are situated within a larger body of legal rules, and so on. But the assumptions are dialectically neutral, and any inferences drawn on their basis provisional. In other words, no philosophical questions of ideal interpretation and explanation are raised or settled in this initial section.

\subsection{Classical Roman law}

Marcus: If then in the majority of nations, many pernicious and mischievous enactments are made, as far removed from the law of justice we have defined as the mutual engagements of robbers, are we bound to call them laws? ...

Quintus: I quite agree with you, and think that no law but that of justice should either be proclaimed as a law or enforced as a law.

Marcus: Then you regard as nullable and voidable the laws of Titius and Apuleius, because they are unjust.

Quintus: You may say the same of the laws of Livius.

-De Legibus I, Marcus Tullius Cicero ${ }^{9}$

8. It is sometimes suggested that the central project of analytic jurisprudence is best understood in terms of real definition or grounding, rather than conceptual analysis. See for example G Rosen, "Metaphysical Dependence and Reduction" in Modality: Metaphysics, Logic, and Epistemology (Oxford University Press, 2010) at 201; A Marmor, "Farewell to Conceptual Analysis (in Jurisprudence)" in W Waluchow \& S Sciaraffa, eds, Philosophical Foundations of the Nature of Law (Oxford University Press, 2013). The ground-theoretic framing of the issues is perfectly compatible with the argument of this paper. Any account of the grounds of law needs to make preliminary use of the concept of law to fix the target of metaphysical explanation. Hence, the philosophy of law can hardly ignore metasemantic questions, even if it remains true that metasemantic questions (or questions of conceptual analysis, conceptual genealogy, and so on) do not exhaust the philosophical enterprise.

9. Cicero, Treatise on the Laws, translated by Francis Foster Barham (Jazzybee Verlag, 2017) at 33 [emphasis added]. 
The conventional view among historians concerning the legal traditions of classical Rome, from the period roughly beginning in the third century BC and ending with the fall of the empire in the fifth century AD, is that magistrates and jurisconsults regularly invoked principles of fairness and equity which they deemed universally applicable "natural laws." ${ }^{10}$ Scholars rely on the evidence of a collection of famous texts, the Corpus Juris Civilis, commissioned by the Emperor Justinian in the first half of the sixth century. ${ }^{11}$ One of these texts, Justinian's Institutes, was intended as an introductory text for new law students in the sixth century, and begins by defining 'jurisprudence' as "the science of the just and the unjust." 12 Justice is in turn defined in terms of three basic principles: "[t]o live honestly, to hurt no one, and to give everyone his due." ${ }^{13}$ What follows is an "exposition of the law of the Roman people," introduced thusly:

The study of law is divided into two branches; that of public and that of private law. Public law is that which regards the government of the Roman Empire; private law, that which concerns the interests of individuals. We are now to treat of the latter, which is composed of three elements, and consists of precepts belonging to natural law, to the law of nations, and to the civil law. ${ }^{14}$

The 'law of nature' is in turn characterized in terms of "rules prescribed by natural reason" (naturalis ratio). ${ }^{15}$ The jurist Ulpian writes in the Digest, the main volume of the Corpus Juris Civilis consisting of juristic commentary on Roman law, "[a] law student at the outset of his studies ought first to know the derivation of the word jus. Its derivation is from justitia. For, in terms of Celsus' elegant definition, the law is the art of goodness and fairness." "16 Ulpian proceeds to give an account of Roman 'private law' in terms of a tripartite division, as "derived from principles of jus naturale [natural law], jus gentium [law of nations], or jus civile [civil law]." ${ }^{17}$ Meanwhile, the 'civil law,' which is "derived from statutes, plebiscites, decrees, [etc.]" is in turn described as:

that which neither wholly diverges from the jus naturale and jus gentium nor follows the same in every particular. And so whenever to the common law we add anything or take anything away from it, we make a law special to ourselves, that

10. See F Pollock, "The History of the Law of Nature: A Preliminary Study" (1902) 2:3 Colum L Rev 131; R Pound, "The Maxims of Equity" (1921) 34:8 Harv L Rev 809; JR Kroger, "The Philosophical Foundations of Roman Law: Aristotle, the Stoics, and Roman Theories of Natural Law" (2004) 2004:3 Wis L Rev 905; PA Vander Waerdt, "Philosophical Influence on Roman Jurisprudence? The Case of Stoicism and Natural Law" in Aufstieg und Niedergang der römischen Welt $(A N R W) /$ Rise and Decline of the Roman World (De Gruyter, 1994) 4851.

11. See WL Burdick, Principles of Roman Law and Their Relation to Modern Law, 3d ed (Lawbook Exchange, 2004) at 3-4.

12. Justinian I, Emperor of the East, Institutes of Justinian, ed \& translated by TC Sandars (Longmans, Green, \& Co, 1917) at 5 s 1.1.1 [Justinian, Institutes].

13. Ibid at $6 \mathrm{~s}$ 1.1.2.

14. Ibid at $6 \mathrm{~s} 1.1 .4$.

15. Ibid at 7 s 1.2 .1 .

16. Ulpian, "Ad Edictum 18" in The Digest of Justinian, translated by C Monro (Cambridge University Press, 1904) at Dig 1.1.1 [Ulpian, Digest].

17. Ibid at DIG 1.1.2. 
is, jus civile, civil law. 1. This law of ours, therefore, exists either in written or unwritten form; as the Greeks put it, 'of laws some are written, others unwritten. ${ }^{18}$

The degree to which Justinian's texts remained faithful to the actual practice of Roman law is controversial. ${ }^{19}$ But the generally accepted position seems to be that Rome's commitment to the laws of justice was not merely theoretical. ${ }^{20}$ Honoré provides a wide range of examples from the Digest of jurists invoking naturalis obligio, naturalis ratio, and naturalis aequitas as a basis for deciding concrete questions of law. ${ }^{21}$ Similarly, Pomeroy notes that magistrates empowered to apply Roman law regularly invoked unwritten laws of justice, and his observations are worth quoting in full:

In their work of improving the primitive jus civile, the [Roman] magistrates who issued edicts .... and the jurisconsults who furnished authoritative opinions ... obtained their material from two sources, namely: At first, from what they term the jus gentium, the law of nations, meaning thereby those rules of law which they found existing alike in the legal systems of all the peoples with which Rome came into contact, and which they conceived to have a certain universal sanction ... and at a later day, from the Stoic theory of morality, which they called lex naturae, the law of nature. The doctrines of this jus gentium and of this lex naturae were often identical... The particular rules of the Roman jurisprudence derived from morality called the law of nature were termed 'aequitas,' from aequum, because they were supposed to be impartial in their operation, applying to all persons alike. The lex naturae were assumed to be the governing force of the world, and were regarded by the magistrates and jurists as having an absolute authority. They felt themselves, therefore, under an imperative obligation to bring the jurisprudence into harmony with this all-pervading morality, and to allow such actions and make such decisions that no moral rule should be violated.... [T] hus a body of moral principles was introduced into the Roman law, which constituted equity. This resulting equity was not a separate department; it penetrated the

18. Ibid at DIG 1.6.1.

19. See Vander Waerdt, supra note 10 at 4879.

20. Ibid at 4851-53. Drawing on the work of Paul Jörs, Römische Rechtswissenschaft zur Zeit der Republik (Hansebooks, 2016), Pound describes Rome's equitable maxims in the following terms: "From recognition that certain regulae, to be discovered and established by juristic research, lay at the foundation of application of law, it was a short step to the wider thought that a lex also need not be regarded as a mere aggregate of precepts but that these precepts themselves are but forms or derivatives of ideas of right which should be formulated theoretically as regulae.' This leads to the philosophical view of ratio ijuris and of all legal rules, whether statutory or traditional or doctrinal, as but expressions of or attempts to formulate principles of natural law ... Roman legal science was never purely theoretical. Application to concrete causes was the end of theory and the end was kept constantly in view." Pound, supra note 10 at 813-14.

21. "'Nature' not merely rules out an obligation to perform what is by nature impossible, but gives reasons for or against rules and institutions. It provides the right of self-defence. It endorses certain modes of acquiring property. Blood relationship is natural. Along with decency, nature condemns incest. It eschews speculation about another's misfortune. It supports the repayment of payments made that were not in fact owed. It allows us consciously to improve the position of others, but not to make it worse. It imposes losses on those who profit from the thing in question. It provides that no one should be enriched by a wrong to another. Some ways of behaving are naturally wrong. The law of nature is always equitable and good." T Honoré, "Ulpian, Natural Law, and Stoic Influence" (2010) 78:1-2 Tijdschrift voor Rechtsgeschiedenis 199 at 204 [citations omitted]. 
entire jurisprudence, displacing what of the ancient system was arbitrary and unjust, and bringing the whole into an accordance with the prevailing notions of morality. ${ }^{22}$

Vander Waerdt writes that "the hypothesis of extensive and substantive Stoic [ethical] influence on Roman jurisprudence is widely regarded as historical fact." 23 And while Vander Waerdt dissents from the orthodox view that the principles of jus naturale were derived specifically from stoic moral theory, he also concludes that Roman jurists habitually appealed to equitable principles "to interpret or to correct received law" and that these "legal doctrines" are the key to understanding "the moral basis of Roman jurisprudence."24

Notably, the legality of the 'laws of justice' is not explained in terms of obedience to customs or conventions. Rather, on Pomeroy's account-who, it should be emphasized, does not have an anti-positivist axe to grind - the legality of equitable principles was presented by jurists as following self-evidently from the fact that the principles conform to requirements of reason and justice. ${ }^{25}$ Moreover, the legality of such principles was expressly distinguished from the legality of rules derived from the customs of nations, even when moral and customary requirements seemed to coincide. ${ }^{26}$ Finally, the jurisconsults conceived of their task as law discovery. ${ }^{27}$ Similar observations have been made by historians concerning the legal culture of ancient Greece. ${ }^{28}$

\subsection{Early modern civilian and common law}

The fact that Roman law influenced the development of civil law on the European continent has been widely documented, but the extent to which moral considerations drove ordinary legal practice under the guise of ' jus naturale' has received

22. JN Pomeroy, A Treatise on Equity Jurisprudence (Bancroft-Whitney, 1907) at 2-3 [emphasis added].

23. Vander Waerdt, supra note 10 at 4853.

24. Ibid at 4895.

25. Ibid. See also Pound, supra note 10 at 813-14.

26. See Pomeroy, supra note 22 at 2-3.

27. Ibid. See also PG Stein, "Roman Law, Common Law, and Civil Law" (1991) 66:6 Tul L Rev 1591 at 1591-92, noting that Roman law "was perceived as essentially law discovered through debates among experts over particular sets of facts."

28. See e.g. JW Salmond, "The Law of Nature" (1895) 11 L Q Rev 121 at 124; Maurice Le Bel, "Natural Law in the Greek Period" (1949) 2 Nat L Inst Proc 3. Le Bel writes, "“natural law' has today a definite Christian connotation; it has none, of course, in pagan Greece, where natural law is considered as a thing of human reason alone... . These precepts are immanent in human nature, they are part of our nature, they are the very expression of the universal notion of justice; they are implanted in us, we would not be what we are without them." Ibid at 9. Le Bel comments further: "I intentionally started with the non-philosophers in order to show that natural law is not a philosopher's conception alone; it was talked about in conversation, it was brought on the stage, it was admitted in the writing of history." Ibid at 17. See also Aristotle, Nicomachean Ethics, translated by WD Ross (Oxford University Press, 2009) at V, vii, 1134b, 25-1135a at 15: "[T] he laws of natural justice ... are universally valid above all human regulations and legally valid." 
far less attention. ${ }^{29}$ A recent study by Helmholz offers a broad-ranging examination of European decisiones (accounts of arguments and decisions in courts) and consilia (legal opinions written by jurists) from 1500 to 1800 AD. ${ }^{30}$ Helmholz observes that "[t]he law of nature, taken up and used as a source of legal argument and decision, appeared within virtually every collection of decisions and consilia consulted.... References to the law of nature were ... clear and repeated in the reports-enough to show that it was not simply abstract jurisprudential theory." 31

One of Helmholz's examples is a case involving unowned property belonging to the first possessor - the holding "was supported by a citation to the law of nature as well as a text from the digest." ${ }^{32}$ In a Florentine case involving a criminal defendant's right to due process, 'a prior precedent's apparent violation of the law of nature was given as the reason for not following it." ${ }^{33}$ On Helmholz's assessment of the caselaw, "[n] atural law was regularly cited in the law of civil and criminal procedure" and "citations of both sources of law (natural and 'positive') made a stronger case." 34 Other legal domains in which jurists referred to considerations of fairness and equity under the rubric of natural law include family law, ${ }^{35}$ criminal law, ${ }^{36}$ commercial law, ${ }^{37}$ and statutory interpretation. ${ }^{38}$ In one example, a church ordinance forbidding the grant of any benefice to descendants of a heretic was declared "odious" and unenforceable for violating a principle of natural justice. ${ }^{39}$

Helmholz observes that this early modern European conception of jus naturale was in core respects similar to classical Rome's. Lawyers were taught that the principles of justice are (a) discovered through rational reflection, (b) exhibit a form of legality with universal application, and (c) can be legitimately relied on in court:

Evidence found in the early European decisiones and works of praxis shows the relevance of the law of nature to what happened in courts. Lawyers put into practice what they had first learned as students. In giving advice and in arguing cases, they drew upon the experience with natural law they had acquired. It served various ends: to create presumptions to interpret statutes, to evaluate commercial transactions, to solve disputes within a family, and to restrain arbitrary exercises of power.... [V]irtually always, it was cited together with precedents from the positive law or ius gentium.... [O]verlap between positive and natural law was actually a sign of the influence of the latter, not an indication of its lack of consequence....

29. See e.g. Burdick, supra note 11 at 3-10; TJ Bochstrasser \& P Schroder, Early Modern Natural Law Theories: Context and Strategies in the Early Enlightenment (Springer, 2003); Pound, supra note 10 at 820-24.

30. See RH Helmholz, Natural Law in Court: A History of Legal Theory in Practice (Harvard University Press, 2015).

31. Ibid at 42 [emphasis added].

32. Ibid at 44.

33. Ibid [emphasis added].

34. Ibid.

35. Ibid at 53.

36. Ibid at 58 .

37. Ibid at 63 .

38. Ibid at 68 .

39. Ibid. 
Where no positive law to govern a particular subject could be found, recourse was to be had to the law of nature. ${ }^{40}$

The influence of Roman legal thought on the development of English common law has, likewise, been well-documented. ${ }^{41}$ Helmholz writes that:

English common lawyers did not customarily use the terms 'Law of Nature' or 'Natural law' in so many words. Instead, they looked to what 'reason' dictated ... thereby applying the same general principles as did the civilians who expressly cited natural law. The words were different, but the substance was not. ${ }^{42}$

He goes on to provide over sixty examples of influential English jurists writing favorably of the 'law of reason' and the 'laws of justice' as a source of English law. ${ }^{43}$ Since this evidence has been effectively documented elsewhere, I limit myself to highlighting a few famous and illustrative cases of juridical commentary concerning the principles.

In Day v Savadge, Chief Justice Hobart observes "even an act of parliament, made against natural equity as to make a man judge in his own case, is void in itself; for jura naturae sunt immutabilia (the Laws of Nature are unchangeable), and they are leges legum (the laws of law)."44 While Hobart declined to read the act at issue in the case as being in conflict with the laws of natural equity, the pleadings seemed to have already conceded the conflict, rendering the natural equity argument legally significant. ${ }^{45}$ In City of London $v$ Wood, Chief Justice Holt reaffirmed the principle of impartiality that a person cannot be a judge in their own cause, while describing as "very reasonable and true" 46 Edward Coke's observations in the leading precedent for the principle, Dr. Bonham's Case: "when an act of parliament is against common right and reason, or repugnant, or impossible to be performed, the common law will control it, and adjudge such act to be void." ${ }^{47}$ In his work on the legal theories that prevailed during this

40. Ibid at 79-80.

41. See e.g. SE Prall, "The Development of Equity in Tudor England" (1964) 8:1 Am J Leg Hist 1 at 18; Pound, supra note 10 at 827-36; RH Helmholz, "Natural Law and Human Rights in English Law: From Bracton to Blackstone" (2005) 3:1 Ave Maria L Rev 1.

42. Ibid at 12. For example, Christopher St Germain, describes the "law of reason" as among the six "grounds of the law of England" and distinguishable from customary law and religious law. Christopher St Germain, Dialogus de fundamentis legum Anglie et de conscientia (Robert Clarke \& Co, 1874) at 1.

43. See Helmholz, supra note 41 at 5-11.

44. (1614), 80 ER 235 at 237.

45. Ibid. "[T] hough in pleading it were confessed, that the custom of certificate of the customs of London is confirmed by Parliament, yet it made no change in this case, both because it is none of the customs intended, and because even an Act of Parliament, made against natural equity ... is void in itself." Ibid. See also CM Gray, "Bonham's Case Reviewed" (1972) 116 Proceedings of the American Philosophy Society 35 at 51.

46. City of London v Wood (1702), 88 ER 1592 at 1602.

47. Thomas Bonham v College of Physicians (1610), 77 ER 646 at 652 [Dr Bonham's Case]. On Coke's ambitious conception of the judge's role, see DEC Yale, "Iudex in Propria Causa: An Historical Excursus" (1974) 33:1 Cambridge LJ 80 at 92; E Corwin, "Higher Law and Constitutional Law" in Richard Loss, ed, Corwin on the Constitution (De Gruyter, 2019). Corwin writes: "One thing seems to be assured at the outset-Coke was not asserting simply a rule of statutory construction which owed its force to the assumed intention of Parliament as it 
period of English history, Hamburger observes that a broad range of jurists were committed to certain fundamental principles of justice being "natural laws" and that "Holt argued that government-including even a representative institution such as Parliament-was subject to natural law."48

In Calvin's Case, Coke refers with exceptional directness to the "Lex aeterna, the moral law, called also the law of nature." 49 Coke's observations concerning the character of these laws are worth highlighting: "this law of nature is part of the laws of England ... the law of nature was before any judicial or municipal law in the world ... the law of nature is immutable, and cannot be changed." ${ }^{, 50}$ Coke cites Aristotle for the proposition that "natural right is that which has the same force among all mankind." 51 Important use was made of 'moral law' in Calvin's Case, which held that all persons born within English territory would enjoy the benefits of English law, allowing the Scottish-born plaintiff to bring a claim against the defendants for dispossessing him of his estate. In developing a precursor to birthright citizenship, Coke asserts that the law of justice was the determining factor in the case. $^{52}$ In a detailed examination of the case and its context, Price writes that Coke's theory was based on the "reciprocal nature of the relationship placed on subject and sovereign," such that "[i]n return for the subject's loyalty, the sovereign owed "protection and government due by the law of nature." 53 Price observes "[ $t]$ he critical result was that allegiance to the English sovereign, and for a time, acquisition of and rights associated with citizenship in the former American colonies, were considered not to be the subject of municipal or positive law-making." 54

The above cases involve influential English jurists invoking moral considerations as supra-constitutional constraints on the legislature while directly attributing legality to basic principles of impartiality and reciprocity. There is also considerable evidence of English courts from this period ostensibly referring to principles of fairness as a form of law, to be weighed together with other 'positive' laws, in ordinary cases at common law and equity; the examples are easily multiplied. ${ }^{55}$

would today, although the statute involved in Bonham's Case was also construed from that point of view ... Coke was enforcing a rule of higher law deemed by him to be binding on Parliament and the ordinary courts alike." Ibid at 111.

48. PA Hamburger, "Revolution and Judicial Review: Chief Justice Holt's Opinion in City of London v Wood" (1994) 94:7 Colum L Rev 2091 at 2093, 2152.

49. Calvin v Smith (1608), 77 ER 377 at 392 [Calvin's Case] [emphasis added].

50. Ibid.

51. Ibid.

52. Ibid at 394. See also PJ Price, "Natural Law and Birthright Citizenship in Calvin's Case (1608)" (1997) 9:1 Yale JL \& Human 73 at 120.

53. Price, ibid at 121, citing Calvin's Case, supra note 49 at 392.

54. Price, supra note 52 at 116.

55. See e.g. Cornfoot v Fowke (1840), 151 ER 450 at 458: "In the case of Hodson v Williamson ... Mr. Justice Yates lays it down as a general proposition, that the concealment of material circumstances vitiates all contracts, upon the principles of natural law. If this be true, can it be doubted that the false representation of a material circumstance also vitiates a contract?" See also Millar v Taylor (1769), 98 ER 201, which held that the Statute of Anne did not extinguish common law rights giving publishers a perpetual copyright to their works. "[T]his, I apprehend, was a necessary ground for the plaintiff to maintain; for, however peculiar the laws of this and every other country may be, with respect to territorial property, I will take upon me to say, that the law of England, with respect to all personal property, had its grand foundation in natural law." Ibid at 


\subsection{Pre-20th century American law}

Several historians have documented the influence of natural law ideas on early American jurisprudence..$^{56}$ In a recent study, Banner writes that " $[\mathrm{b}]$ efore the late 19th century, natural law played an important role in the American legal system. Lawyers routinely used it in their arguments and judges often relied upon it in their opinions." ${ }^{57}$ The popularity of the 'laws of justice' is reflected in an observation of Holmes' from 1918 that "[t]he jurists who believe in natural law seem to me to be in that naïve state of mind that accepts what has been familiar and accepted." ${ }^{\prime 58}$ As above, rather than reviewing the historical literature in detail, I restrict myself for reasons of space to a few illustrative examples of case law from this period. These cases have not previously been discussed, as far as I am aware, despite the exceptionally clear treatment of unsourced principles of fairness as bona fide law.

A set of cases from the 19th century involved a question of state constitutional law: whether a state that confiscates private property on behalf of the public owes the burdened person fair compensation. While the U.S. Constitution mandates compensation, the Fifth Amendment, as originally written, restricted only the federal government from uncompensated takings, and it was not until after the civil war that the Bill of Rights was applied against state governments through the passage of the Fourteenth Amendment. ${ }^{59}$ Before then, many state constitutions included a provision analogous to the federal takings clause, but some omitted it. ${ }^{60}$ It was in this context that the New York Chancery Court derived a duty of compensation constraining legislative powers to take private property from a putative law of natural equity:

229. "It is certainly not agreeable to natural justice, that a stranger should reap the beneficial pecuniary produce of another man's work. Jure naturce cequum est, neminem cum alterius detrimento et injuria fieri locupletiorem." Ibid at 223. See also Gurney v Hardenberg (1908), 127 ER 923, which held that a defendant's property could be levied despite the defendant's lack of presence in England: "it is strange that such a practice should have so long prevailed in this court, since however it is established, it must prevail now, but it appears to me repugnant to the principles of law and the principles of justice. The same thing is law and justice in this court," ibid at 924; Wright $v$ Simpson (1902), 31 ER 1272 at 1275: "the equitable jurisdiction is more enlarged; proceeding upon principles of universal justice; which must not be defeated by slight obstacles . . . Formerly Courts of Law would not advert to such considerations: of late they have made some progress in that way; but they have not gone the length of Courts of Equity."

56. See S Banner, The Decline of Natural Law: How American Lawyers Once Used Natural Law and Why They Stopped (Oxford University Press, 2021). See also ES Corwin, "The 'Higher Law' Background of American Constitutional Law” (1928) 42:3 Harv L Rev 365; TC Grey, "Origins of the Unwritten Constitution: Fundamental Law in American Revolutionary Thought" (1978) 30:5 Stan L Rev 843 at 859-65; PA Hamburger, "Natural Rights, Natural Law, and American Constitutions" (1993) 102:4 Yale L J 907. See also State v Joyner, 625 A (2d) 791 (Conn 1993) at 814, noting that a commitment to natural law "pervaded eighteenth century legal thought throughout America, including Connecticut."

57. Banner, supra note 56 at 1.

58. OW Holmes, "Natural Law" (1918) 32:1 Harv L Rev 40 at 41.

59. Barron v Mayor and City Council of Baltimore, 32 US ( 7 Pet) 243 (1833) at 247, held that the Bill of Rights did not apply to the States.

60. See Orr v Quimby, 54 NH 590 (1874) at 647 [Quimby]. 
I am not to be understood as denying a competent power in the legislature to take private property for necessary or useful public purposes.... But to render the exercise of the power valid, a fair compensation must, in all cases, be previously made to the individuals affected, under some equitable assessment to be provided by law. This is a necessary qualification accompanying the exercise of legislative power, in taking private property for public uses; the limitation is admitted by the soundest authorities, and is adopted by all temperate and civilized governments, from a deep and universal sense of its justice. Grotius, (De Jur. B. \& P. b. 8. ch. 14. s. 7.) Puffendorf, (De Jur. Nat. et Gent. b. 8. ch. 5. s. 7.) and Bynkershoeck, (Quæst. Jur. Pub. b. 2. ch. 15.) when speaking of the eminent domain of the sovereign ... all lay it down as a clear principle of natural equity, that the individual, whose property is thus sacrificed, must be indemnified. ${ }^{61}$

The court admits that there was no compensatory duty to be found in the New York constitution, unlike the constitutions of other states. ${ }^{62}$ Its justification for imposing the duty is a 'principle of natural equity' along with citations to Samuel von Pufendorf and Hugo Grotius who famously argued for natural laws of justice constraining the powers of government. ${ }^{63}$

The holding in Gardner v Village of Newburgh prevailed in New York until a constitutional provision requiring compensation was officially adopted. ${ }^{64}$ However, prior to adoption, at the proceedings of the New York Convention in 1821, there was general concurrence that the provision was unnecessary. ${ }^{65}$ In Bradshaw $v$ Rodgers, the court held that the constitutional provision was merely 'declaratory' of a principle of justice which applied independently in the case:

[The act which allows taking of property without compensation] is directly opposed to the fifth article of the amendments of the constitution of the United States, which forbids the taking of private property for public use, without just compensation. The same inhibition to the power of the legislature, is contained in the late amendments to the constitution of this state. I do not rely on either, as having a binding constitutional force upon the act under consideration. The former related to the powers of the national government, and was intended as a restraint on that government; and the latter is not yet operative. But they are both declaratory of a great and

61. Gardner v Village of Newburgh, 2 Johns Ch 162 (NY Ch 1816) at 166 [Gardner] [emphasis added].

62. Ibid. The holding is interpretated by subsequent courts as deriving a compensatory duty from a 'law of natural justice.' See e.g. discussion in Quimby, supra note 60.

63. See H Grotius, On the Law of War and Peace, translated by William Whewell (Cambridge University Press, 1853) at BK I, ch I, sec x, para 1: "The law of nature is a dictate of right reason, which points out that an act, according as it is or is not in conformity with rational nature, has in it a quality of moral baseness or moral necessity; and that, in consequence, such an act is either forbidden or enjoined." On Pufendorf's view, see e.g. C Korsgaard, Sources of Normativity (Cambridge University Press, 1996) at 7, 21-22, 28-30.

64. The holding was not overruled in Bloodgood v Mohawk \& Hudson RR Co, 18 Wend 9 (NY 1837).

65. See Quimby, supra note 60 at 648-9. 
fundamental principle of government; and any law violating that principle must be deemed a nullity, as it is against natural right and justice. ${ }^{66}$

The court could not have stated in clearer terms that it took the "fundamental principle ... [of] natural right and justice" to legally constrain the legislature independently of the constitutional provisions requiring fair compensation, whether at the state or federal level: "I do not rely on either, as having binding constitutional force upon the act under consideration." ${ }^{967}$

The New York approach attracted notable critical commentary from a justice in New Hampshire. In Orr v Quimby, the judge rejects the New York approach, which it deems as having influenced New Hampshire: ${ }^{68}$

New Hampshire is not the only state in which the constitutional view has been darkened by doctrines of natural justice, and theories of the highest law.... The legislative power of New York was restricted by a duty of compensation, imposed not by a judicial interpretation of any particular passage of the constitution, not by any reasoning tending to show that 'the supreme legislative power' was not to be understood in its English sense ... but by a judicial usurping administration of the higher law of natural justice. ${ }^{69}$

The opinion is worth reading in full. It leaves a powerful impression that the judges disagreeing on the force of moral considerations fully understood the distinction between an extra-legal body of norms and bona fide juridical law. Likewise, they understood the distinction between juridical law derived from custom, tradition, statutes, legislative intent, or constitutional text, and juridical law derived, more controversially, from unsourced principles of justice. ${ }^{70}$

There are other, more famous examples of appeals to laws of natural equity in American jurisprudence from the founding era. ${ }^{71}$ An overlooked example involved foreign debts. Immediately after American independence, the Virginian legislature passed an act purporting to discharge debts owed by American citizens to British creditors. ${ }^{72}$ The Virginia High Chancery Court held

66. 20 Johns 103 (NY Sup Ct 1882) at 106 [Bradshaw] [emphasis added]. See also Cairo \& FR Co $v$ Turner, 31 Ark 494 (1876) [Cairo] at 499 [emphasis added]: "The duty to make compensation for property taken for public use, is regarded, by most enlightened jurists, as founded in the fundamental principles of natural right and justice, and as lying at the basis of all wise and just government, independent of all written constitutions or positive law."

67. Bradshaw, supra note 66 at 106.

68. See Quimby, supra note 60 at 605.

69. Ibid at 647 [emphasis added].

70. See ibid at 609: "[J]udicial construction, that is, finding the legal meaning of words used by parliament [stands in] striking contrast with the power of holding that an unjust statute, when its legal meaning is found, is void on the ground that parliament has no authority to make an unjust law."

71. See e.g. Calder v Bull, 3 US (3 Dall) 386 (1798) at 388; Commonwealth V Jennison (1783), Proceedings of the Massachusetts Historical Society 1873-1875 at 293, 293-94; JD Cushing, "The Cushing Court and the Abolition of Slavery in Massachusetts: More Notes on the 'Quock Walker Case"” (1961) 5:2 Am J Legal Hist 118; Robin v Hardaway, 1 Jefferson 109 (Va 1772) at 114; G Ablavsky, "Making Indians 'White': The Judicial Abolition of Native Slavery in Revolutionary Virginia and its Racial Legacy" (2011) 159:5 U Pa L Rev 1457 at 1487.

72. See Page v Pendleton, Wythe 211 (Va High Ch 1793) at 212-13 [Pendleton]. 
that the right to money owed to the "enemy" could not be extinguished by the legislature of the debtor's country because of the "laws of nature" which "men, who did not ordain them, have not power to abrogate."73 In response to an objection drawn from the Virginian Bill of Rights that "men are not bound by laws to which they have not, by themselves, or by representatives of their election, assented,"74 the court observed that the requirement of assent only applies to "positive law" and not to the "law[s] of nature [which] harmonize with our innate notions of rectitude" and "are, as Antigone says to Creon, in Sophocles, unwritten laws." 75 Among the unwritten laws of justice, the court includes: "the prohibition to kill or wound our fellow men, to defame them, to invade their property, the praecepts to deal faithfully, to make reparation for injury."76

\subsection{Summary}

To reiterate a point conceded at the outset, a few illustrative cases and a sampling of historical scholarship is no substitute for a comprehensive assessment of how jurists have thought about law throughout history. Nevertheless, the verdict of historians and the explicit discussion of the laws of justice found in influential legal texts and famous judicial opinions justify taking the possibility seriously that moral principles were once commonly thought to exhibit a form of legality. At the very least, we have grounds for provisionally accepting the following observations for purposes of philosophical exploration:

1. Judges (and other ordinary legal officials) have, in a natural context for the use of legal terminology, attributed legality to what they take to be moral principles, using these alleged laws of justice to provide compensation for property taken in the absence of constitutional requirements, to preclude states from interfering with financial obligations owed to foreign creditors, to ensure impartial adjudication, to determine equitable remedies, to establish rights to protection under law, to convict agents perpetrating injustice under the authority of enacted law, and in various other ways.

2. These jurists did not explain the legality of moral principle by adverting to social facts, judicial choice, or more fundamental laws; on the contrary, they seemed to treat 'moral laws' as self-evident, unchangeable, and applicable ex proprio vigore, expressly distinguishing such laws from enacted laws and customary laws.

3. Jurists have cited the 'laws of justice,' along with ethical treatises which purport to clarify basic moral requirements, when using them to decide cases.

4. The juridical idea that 'what is good and equitable' is both law and a necessary constraint on positive law (the 'law of laws') can be traced at least as

73. Ibid at 214 .

74. Ibid.

75. Ibid.

76. Ibid. 
far back as to a classical Roman conception of moral principles as lex naturae, the law of nature, which medieval and early modern civil lawyers likewise conceived of as a form of law revealed through rational reflection. The view seems to have influenced early Anglo-American constitutional jurisprudence.

Note that these observations do not involve taking a definitive stand on the nature or normative content of moral principles. For our purposes, it is enough that the principles invoked as 'laws of natural justice' have a plausible claim to mirroring genuine moral requirements. Recall, for example, Antigone's principles requiring persons 'to live honestly, to hurt no one, and to give everyone his due'; to avoid being 'judge in their own cause'; to honor 'the prohibition to kill or wound our fellow men, to defame them, to invade their property' as well as 'the praecepts to deal faithfully, to make reparation for injury.' In other words, the principles invoked by jurists as 'moral law' are not so obviously instances of ideology and social control masquerading as justice. In what follows, we can set modern legal practice largely aside or, rather, grant that the 'laws of justice' do not turn up with the same frequency or explicitness in contemporary jurisprudence. ${ }^{77}$

\section{Hart-Dworkin on Moral Principles}

Before turning to our explanatory puzzle, it is worth briefly noting that the historical treatment of moral principles has not attracted much commentary from legal philosophers. ${ }^{78}$ Consider the following passage from Hart's The Concept of Law:

procedural standards such as 'audi alteram partem' [and] 'let no one be a judge in his own cause' are thought of as requirements of justice, and in England and America are often referred to as principles of natural justice. This is so because they are guarantees of impartiality or objectivity, designed to secure that the law is applied to all those and only to those who are alike in the relevant respect marked out by the law itself. ${ }^{79}$

77. On natural law's decline in Anglo-American jurisprudence, see Banner, supra note 56. Its general disappearance is contestable. For example, von Hippel provides examples of post-1947 German courts invoking "moral law," "material justice," and "suprapositive principles of justice which underlie all written law." E von Hippel, "The Role of Natural Law in the Legal Decisions of the German Federal Republic" (1959) 42 Natural Law Forum 106 at 113, 111-115. See also KA Adams, "What is Just?: The Rule of Law and Natural Law in the Trials of Former East German Border Guards" (1992) 29:2 Stan J Int'l L 271 at 297, 301.

78. Natural law theorists seem aware of this history but have not deployed it in philosophical argument. Finnis, for example, observes in passing that 'pre-modern legal vocabulary' seemed connected to justice, but does not articulate for positivists a challenge based on this conceptual history; see J Finnis, Natural Law \& Natural Rights, 2d ed, (Oxford University Press, 2011) 206-10. See also L Fuller, "Positivism and Fidelity to Law-A Reply to Professor Hart" (1958) 71 Harv L Rev 630 at 646-60; J Crowe, Natural Law and the Nature of Law (Cambridge University Press, 2019).

79. Hart, supra note 4 at 160 [emphasis added]. 
Two famous principles of adjudication are mentioned in this passage, but the quoted remarks constitute the entirety of Hart's discussion of the principles, which is surprisingly brief. As discussed, the principle no person shall be a judge in their own cause is associated with a famous line of English cases, and Hart's claim that it was 'often referred to as a principle of natural justice' obscures the full picture. Influential jurists referred to the principle as a 'law of justice,' as an 'unchangeable law,' as 'moral law,' and, even, the 'law of laws' in the context of deciding cases. ${ }^{80}$ Moreover, these jurists purported to explain why principles of impartiality count as law, and their relationship to other laws of the system. These details matter for purposes of evaluating competing philosophical explanations of judicial practice. For example, the classification of principles of impartiality as law in a natural context for the use of juridical terminology bears (even if non-decisively) on whether judges have treated these principles as 'extra-legal' bases for deciding cases. ${ }^{81}$ And a characterization of the principles as unchangeable laws casts doubt on the idea that jurists treated the legality of the principles as dependent on local customs.

Even Dworkin's famous challenge for positivists based on the role of equitable principles in adjudication overlooks historical practice. Various details of the argument can be suppressed, but its central and least question-begging observation is that modern judges tasked with figuring out what the law is frequently base their conclusions partly on considerations of justice. ${ }^{82}$ For example, a judge might regard the fact that a contractual provision takes 'unfair' advantage of the buyer as a reason for deeming the provision unenforceable as a matter of law. ${ }^{83}$ So, the argument goes, moral principles appear to be a ground of law. The standard positivist replies to Dworkin's challenge are well-known. 'Inclusive' positivists point out that the moral principles in question may be law (or determinants of law) not on moral grounds but in virtue of the social fact that prior judges have embraced the principles. ${ }^{84}$ 'Exclusive' positivists point out that judges rely on all kinds of extra-legal rules or principles in adjudication (principles of logic, grammar, statistics, and, indeed, morality), but that does not necessarily make the relied-on principles law. ${ }^{85}$ Dworkin finds himself vulnerable to these replies for focusing on just one aspect of judicial reasoning in relation to

80. The leading precedent being Dr Bonham's Case, supra note 47. See discussion in $\S 1.3$.

81. Hart does engage and critique the natural law theorists, but attends to philosophical arguments, not the actual practice of law and ordinary juristic intuition; see Hart, supra note 4 at 185-213. See also HLA Hart, "Positivism and the Separation of Law and Morals" (1958) 71:4 Harv L Rev 593 at 594-95. As I argue below, what needs to be explained is the convictions of ordinary legal officials.

82. Dworkin develops the argument in several classic articles; see generally Dworkin, supra note 5. For a useful summary of the core of Dworkin's challenge, see C Nino, "Dworkin and Legal Positivism" (1980) 89:356 Mind 519.

83. See e.g. Henningsen v Bloomfield Motors Inc, 161 A (2d) 69 (NJ 1960) [Henningsen]; Dworkin, "Model of Rules", supra note 5 at 20-25.

84. See e.g. JL Coleman, The Practice of Principle: In Defense of a Pragmatist Approach to Legal Theory (Oxford University Press, 2001) at 67-68,103-19,151-52; W Waluchow, Inclusive Legal Positivism (Oxford University Press, 1994) at 185-86.

85. See e.g. J Raz, Practical Reason and Norms, 2d ed (Oxford University Press, 1990) at 152-54; SJ Shapiro, Legality (Harvard University Press, 2011) at 272. 
moral principles (adjudicative reliance), in a small selection of illustrative cases (two in Model of Rules), from a unique area of law (common law), in a unique legal system (American), at a unique point in time (the contemporary period). ${ }^{86}$ As $\S 1$ highlights, ordinary jurists from a broad range of legal systems have treated moral principles in more complex ways than simply relying on them in adjudication. In $\S 4$, I argue that the complexion of the Hart-Dworkin debate seems to change when viewed through the lens of legal history. The limited point for now is that the history of the laws of justice does not receive much consideration under the terms of this classic debate.

\section{Positivism's Trilemma Assuming a Historically Continuous Concept of Law}

An adequate account of the nature of legality should be able to explain why jurists in prior legal systems classified moral principles as law. This section explores the prospects of a positivist-friendly explanation that starts with the assumption that classical Romans, early modern Europeans, and founding-era Americans shared the same concept of law as contemporary jurists (henceforth, 'the common concept assumption'). The assumption limits the positivist to the following three explanatory strategies: (i) vindicate the legal intuitions of past jurists by appeal to positivist criteria for law; (ii) dismiss their judgments as insincere; or (iii) convict them of legal error. The positivist can always adopt a mixed approach, explaining some of the judgments as true, others as insincere, and still others as mistaken. But that is no mark against the taxonomy or the overall argument of this section when one of its central points is that we should seek a unified explanation for a phenomenon that appears unified: jurists across the centuries have behaved in very similar ways and said very similar things about the laws

86. See Dworkin, "Model of Rules," supra note 5 at 20-25. Dworkin relies on Henningsen, supra note 83 , where the legal question concerned the scope of an automobile manufacturer's ability to contractually limit its liability. The court based its interpretation of the warranty on the fact that "courts generally refuse to lend themselves to the enforcement of a 'bargain' in which one party has unjustly taken advantage of the economic necessities of the other." Ibid at 86. Dworkin's other main example is Riggs v Palmer, $22 \mathrm{NE} 188$ (NY 1889) at 189 [Riggs]. "In Riggs, the court cited the principle that no man may profit from his own wrong as a background standard against which to read the statute of wills and in this way justified a new interpretation of that statute." Dworkin, "Model of Rules," supra note 5 at 29. Dworkin argues that the positivist cannot capture the legality of the principles relied on in Riggs and Henningsen: "The positivist cannot defend his theory ... by fiat; if principles are not amenable to a [positivist] test he must show some other reason why they cannot count as law. Since principles seem to play a role in arguments about legal obligation (witness, again, Riggs and Henningsen), a model that provides for that role has some initial advantage over one that excludes it." Ibid at 37. He continues: "Most rules of law, according to Hart, are valid because some competent institution enacted them.... But this test of pedigree will not work for the Riggs and Henningsen principles. The origin of these as legal principles lies not in a particular decision of some legislature or court, but in a sense of appropriateness developed in the profession and the public over time." Ibid at 41. It is widely appreciated that Dworkin misinterprets Hart's view by ignoring the possibility of general customs being a source of valid law. The 'sense of appropriateness' in the profession may be deference to custom, rather than owing to the morality of the relevant principles independently of custom. 
of justice. Moreover, the problems with each of the three explanatory strategies I discuss below are not of the kind to be solved by combining strategies.

\subsection{Conventionalism}

Consider, first, the prospects of explaining the observed legal judgements in terms of the kinds of social facts that positivists think determine the law. The principles that early modern civilian and common lawyers described as 'natural laws' were widely followed, and it may have been general compliance with the principles, rather than their moral content, that determined their legality. Put differently, the principles in question may have been a form of 'customary law,' consistent with the truth of legal positivism. ${ }^{87}$ Alternatively, jurists who decided cases by appeal to equitable principles may have been exercising law-making powers they enjoyed based on customary rules of adjudication. These broadly 'conventionalist' strategies are familiar from positivist replies to Dworkin's original challenge based on modern practice. ${ }^{88}$

Conventionalism Jurists who classified principles of justice as law did so because the principles were widely embraced, or because local customs authorized these jurists to make new law.

The conventionalist reply may have been a satisfactory response to Dworkin's challenge, but its present application is contestable for at least two reasons. First, the evidence indicates that jurists did not advert to social facts to explain the 'laws of justice.' Their failure to do so is significant because in general judges and other legal experts readily appeal to such facts in explanation. When the legality of a rule or principle is based on precedent, prior judicial recognition, or law-making authority, judges appreciate the importance of making these explanatory connections explicit and are adept at doing so. Furthermore, judges know how to deem a rule or imperative 'extra-legal' or as stemming from 'powers outside of law. ${ }^{19}$ So, the conventionalist owes us an explanation for why judges invoking the 'laws of justice' were not similarly disposed to explain the legality of principles of fairness or impartiality in terms of background conventions, customs, or law-making powers.

Second, and more worryingly, the proposal flatly contradicts explicit juristic commentary on the nature of the moral laws, commentary which strongly suggests that jurists did not believe that the legal status of moral principles depends on local customs. Judges have described the laws of justice as an original basis for deciding cases while invoking principles not previously recognized by courts. ${ }^{90}$ In the New York

87. We can grant for argument's sake that the content of the relevant principles can be captured by a customary rule.

88. See Coleman, supra note 84 at 67-68; Waluchow, supra note 84 at 185-86.

89. See e.g. Hamburger's account of the treatment of binding Royal prerogatives by English courts in $P$ Hamburger, Law and Judicial Duty (Harvard University Press, 2008) at 22-26. With or without statutory foundations, the King's prerogatives were often deemed 'extra-legal' imperatives.

90. See Calvin's Case, supra note 49; Gardner, supra note 61; Bradshaw, supra note 66; Cairo, supra note 66; and accompanying texts. 
takings case described earlier, the court admits that the state constitution is not the source of the law that obliges the state to compensate a private party for publicly possessed property. ${ }^{91}$ The constitution is acknowledged as being 'silent' on the matter. ${ }^{92}$ The common law, construed as a "mere mass of customs," as one New Hampshire court put it, cannot explain a judge's use of the "laws of natural justice" to constrain the legislature. ${ }^{93}$ Furthermore, jurists were willing to declare that "no power on earth"- which includes, one assumes, the power of shifting legal conventions in the jurisdiction - could invalidate such moral laws or the judge's responsibility to apply them. ${ }^{94}$ "Man-made law," we are told, cannot go against moral law. ${ }^{95}$ The unwritten laws of justice, according to one court, do not require the 'assent' of a legislature or the general public to be legally binding on both. ${ }^{96}$ Recall the especially direct terms in which Coke describes the "Lex aeterna, the moral law, called also the law of nature," as "immutable ... and ... part of the laws of England."97

Likewise, when classical Roman magistrates and jurisconsults reasoned about the legal status of moral principles, they seem to have explicitly distinguished laws derived from custom from the 'laws of nature,' even where the two coincided. ${ }^{98}$ And, as Helmholz notes, early modern European courts distinguished principles they believed were implicit in custom from principles believed to be the laws of reason and justice with universal application, the latter sometimes contradicting the prevailing customary norms. ${ }^{99}$ Moreover, "overlap between 'positive' and natural law" was seen as "a sign of the influence of the latter, not an indication of [natural law's] lack of consequence."100 Accordingly, it seems anachronistic to superimpose on these jurists a commitment to only recognizing the legal validity of moral principles if custom allows it.

The positivist can always maintain that past jurists were confused about why the laws of justice count as law, but then the explanation becomes a version of error theory. Error-theoretic explanatory strategies generate distinct problems that I discuss separately in $\$ 3.3$. The point for now is that a purely vindicating strategy like CONVENTIONALISM that portrays jurists as having classified moral principles as law due to legal customs (or law-making powers) is very hard to square with their actual commentary.

91. See Gardner, supra note 61 and accompanying text.

92. See Quimby, supra note 60 at 605,647 . See also Cairo, observing that "[t]he duty to make compensation for property taken for public use, is regarded, by most enlightened jurists, as founded in the fundamental principles of natural right and justice, and as lying at the basis of all wise and just government, independent of all written constitutions or positive law." Cairo, supra note 66 at 499 [emphasis added].

93. Quimby, supra note 60 at 636.

94. Pendleton, supra note 72 at 213.

95. Ibid.

96. Ibid.

97. Calvin's Case, supra note 49 at 392.

98. See Pomeroy, supra note 22 and accompanying text.

99. See Helmholz, supra notes $30-40$ and accompanying text.

100. Helmholz, supra note 30 at 79-80. 


\subsection{Fictionalism}

Consider, next, a broadly fictionalist approach to explaining the highlighted legal usage. $^{101}$

FICTIONALISM Judges who invoked the 'laws of justice' were aware that moral principles aren't really law. Their pretense was aimed at promoting justice while keeping up the façade of strict obedience to law. Since such talk among jurists is insincere, it is entirely compatible with the true grounds of legality being social. ${ }^{102}$

Charges of legal disingenuousness can vary in severity. ${ }^{103}$ Leiter observes that a harsher version of this charge implies conscious dishonesty, whereas a milder version attributes self-deception "because of the familiar psychological and emotional influences on human decision-making in the heat of a legal dispute."104 The milder notion that jurists might be mistaken due to motivated reasoning amounts to a kind of error theory, which I'll consider in the section to follow. For now, fictionalism in my stipulated sense involves the sharper accusation of conscious deception.

101. On the different varieties of fictionalism, see S Yablo, "Go Figure: A Path Through Fictionalism" (2001) 25:1 Midwest Studies in Philosophy 72. The specific brand of fictionalism I have in mind, here, is 'instrumentalist' in Yablo's taxonomy: judges do not intend the literal content of their legal assertions, while intending to convey the impression that they are speaking literally for instrumental reasons. A different kind of view, which Yablo calls 'metafictionalism,' is not this section's intended target. This view portrays speakers as intending to communicate something other than the literal assertion. E.g., a metafictionalist might paraphrase 'Sherlock Holmes lives in London' as 'according to the fictional work by Arthur Conan Doyle, Sherlock Holmes lives in London.' A metafictionalist account of a set of claims does not treat those claims as false or intentionally misleading. Metafictionalist accounts of legal assertion are best analyzed under the node of conventionalism in my taxonomy. E.g., a metafictionalist might argue that judges who asserted 'moral principles are law' really intended to say something like 'around here, we treat moral principles as law,' which the positivist might try to vindicate as true. Such views are not supported by the contextual or linguistic evidence for reasons discussed in \$3.1.

102. See A Marmor, Philosophy of Law (Princeton University Press, 2010) at 66, who observes that judicial reliance on moral principles "has the status of an inconvenient truth ... [a]nd this inconvenience puts judges under considerable pressure to coat the making of new law in the rhetoric of law application." See also B Leiter, "Explaining Theoretical Disagreement" (2009) 76:3 U Chicago L Rev 1215 at 1224-25; SJ Shapiro, "The 'Hart-Dworkin' Debate: A Short Guide for the Perplexed" in A Ripstein, ed, Ronald Dworkin (Cambridge University Press, 2007) at 39-40; D Plunkett \& T Sundell, "Dworkin's Interpretivism and the Pragmatics of Legal Disputes" (2013) 19:3 Leg Theory 242. Plunkett and Sundell defend a general metasemantics for legal terms which, I would argue, is aptly characterized as a kind of qualified fictionalism about legal discourse. They argue that a central feature of using legal language is negotiating the meaning of 'law' by deliberately using it in ways that flout the conventional criteria associated with the term's use. There is a kind of license, in other words, possibly appreciated by core participants in the linguistic practice, to make claims of law the speaker knows to be false (e.g., 'the principles of justice are law') but hopes will eventually be accepted by others resulting in a shift in the meaning of legal expressions. The Plunkett \& Sundell proposal, on the fictionalist interpretation, attributes considerable lack of forthrightness to core participants in legal practice and is vulnerable to the objections I go on to raise.

103. See Leiter, supra note 102 at 1224-25.

104. Ibid at 1225 . 
There are several problems with the proposal which together make FICTIONALISM seem evasive and unsatisfying. First, the fictionalist posits a deliberate fraud that has endured over many centuries, across a wide range of jurisdictions, in which Roman jurisconsults, famous English jurists, and founding-era American judges have all been complicit. Yet there are no 'winks' and 'nods' to be found in the behavioral evidence. There are no contexts, including outside the courtroom or in private correspondence, where jurists like Coke and Holt acknowledge their alleged pretense, as far as we are aware. And historians seem to have taken these jurists at their word. To be sure, contemporary judges sometimes admit to having made exaggerated claims about the extent of legal determinacy and the like. ${ }^{105}$ But those who invoked laws of reason and fairness seem sincere in their commentary, and the earnestness of these jurists constitutes evidence against FICTIONALISM, even if it isn't decisive evidence.

Second, the more uncharitable an explanation, the more closely it must be examined to ensure it isn't motivated solely by a desire to save one's preferred theory from inconvenient facts; and it is unclear what evidence the fictionalist could possibly draw on to motivate this specific charge of rampant dishonesty. To be sure, bad faith is often inferable from the kinds of arguments legal officials offer in defense of their legal claims. Judges frequently make claims about what precedent establishes or what the empirical evidence suggests that seem motivated by the judge's political preferences rather than a considered take on law and fact. ${ }^{106}$ In such cases, charges of bad faith are plausible precisely because they are based on a critical examination of the judge's arguments. But there are no such arguments to critique in the case of jurists sympathetic to the laws of justice, since they seem to have treated the legality of moral principles as basic, intuitive, and not requiring independent justification. The laws of justice and impartiality "do not admit of proof by reason and argument but bear with them their own evidence." 107 In other words, these jurists do not seem to be behaving in ways that fit the stereotype of bad faith judging; and, in any case, it would be unreasonable to convict past jurists of dishonesty-conveniently those whose legal intuitions conflict with positivism-based on nothing more than a stereotype.

Third, fictionalism's assumptions about the motives of jurists are questionable. There may be good reasons for contemporary judges to be less than transparent about the role of moral considerations in law. For example, modern American judges might have reasons for misrepresenting their extra-legal reliance on moral principles in a pluralistic democracy characterized by pervasive moral disagreement. ${ }^{108}$ But classical Roman jurisconsults and early modern civilian lawyers, one imagines, would

105. Ibid at 1225 .

106. Ibid at 1247 . Leiter is surely right that a failure to notice how often judges engage in "interpretive opportunism" reflects "a kind of naivety about legal practice." Ibid at 1242, 46.

107. Corwin, supra note 47 at 103-04, citing John Fortescue, Henry VI's Chief Justice, in De Laudibus.

108. See generally S Altman, "Beyond Candor” (1990) 89 Mich L Rev 296. 
have been far less sensitive to democratic values or problems of moral pluralism. ${ }^{109}$ At the very least, it is unclear what powerful reason they would have had to pretend, so persistently, that principles of fairness and equity are law. The fictionalist gambit seems markedly anachronistic.

\subsection{Error theory}

Since the previous two strategies are subject to serious challenge, a positivist committed to the common concept assumption may be tempted to characterize the moral law conviction as a pervasive error.

ERROR THEORY Jurists who believed that some moral principles are universally valid law were all mistaken.

The error theorist avoids the problems facing the conventionalist and the fictionalist by taking the juristic claims and contextual evidence at face value. But error theory confronts a different problem by incurring a unique explanatory burden that the positivist is not well-placed to meet-that of explaining, in terms of the nature and determinants of legality, why legal experts would have mistakenly assumed that moral principles are a form of basic and a priori law.

We can begin by motivating the explanatory burden. The fact that jurists make mistakes about the law, including about its sources, content, or righteousness, can hardly be denied. But one would expect certain common or widespread errors about legal content to be reasonably related to the determinants of legality. ${ }^{110}$ In other words, a theory of the grounds of law can be evaluated based on, among other criteria, how well the theory explains the systematic errors about the law it implies. For example, a theory according to which the law is fundamentally determined by people's intentions seems well-placed to explain why jurists and other legal experts tend to misidentify the law when the intentions of relevant individuals, say, constitutional framers or legislators, are hard to discern. Other kinds of errors may not be so easily explained, however. And a theory is less than satisfying if it implies not just that jurists are legally mistaken, but that their mistakes are inexplicably arbitrary, bearing little to no connection to the nature of law. ${ }^{111}$ More generally,

109. Accordingly, when Marmor observes that the fact that judges rely on moral principles is an "inconvenient truth," surely the point must be limited to contemporary jurisdictions. Marmor, supra note 102 at 66. For many centuries, judges were transparent about deciding cases based on moral principles.

110. After all, when large numbers of individuals with apparent expertise about a subject (say, combustion) end up with false beliefs (consider the 18th century belief in phlogiston), such beliefs are typically explainable as good faith and understandable errors (phlogiston seemed to explain genuine and previously unexplained features of combustion). See VD Boantza \& O Gal, "The 'Absolute Existence' of Phlogiston: The Losing Party's Point of View" (2011) 44:3 British Journal of Historical Science 317.

111. See generally E Hirsch, "Against Revisionary Ontology" (2002) 30:1 Philosophy Topics 103 at 116, arguing that considerations of charity entail that philosophers should interpret people's utterances without attributing unexplained a priori errors to them; Dan Korman, 
Kovacs argues based on a principle of interpretive charity that a philosophical error theory is only as plausible as the explanations it provides for (a) why ordinary, non-philosophical beliefs systematically come apart from the truth, and (b) why the mistaken beliefs remain more or less reasonable. ${ }^{112}$

Another way to motivate the explanatory burden is by analogy to a demand for explanation pressed by positivists against anti-positivists. Mainstream varieties of anti-positivism take moral facts to essentially constrain legal content in ways that render grossly immoral laws impossible. These views seem to entail that many immoral laws upheld by contemporary judges were not really law: fugitive slave laws, racial segregation laws, overharsh criminal laws, and so on. ${ }^{113}$ Antipositivism thus seems inconsistent with ordinary legal intuition, and positivists rightly observe that, at the very least, the anti-positivist bears a burden of explaining why legal experts make the pervasive error of thinking an unjust law is still law. For analogous reasons, positivists need to explain why past jurists were mistakenly drawn to the view that moral principles exhibit an a priori form of legality.

This genuine explanatory burden is not one that the positivist is wellpositioned to meet. For example, the positivist might be tempted to invoke the subtlety of philosophical arguments as an explanation. Perhaps jurists over the centuries were simply misled by unsound arguments developed by philosophers of natural law, including Aristotle, Aquinas, Grotius, and others-arguments concerning law's function, legal determinacy in hard cases, and so on. These complex arguments are mistaken, according to the positivist, but they are not obviously mistaken. ${ }^{114}$ Accordingly, the observed error among jurists who thought unsourced principles of justice are law can be explained charitably: reasonable people can easily be misled by philosophical considerations.

The problem with the 'philosophy is hard' response is that it is very unlikely that the broad range of ordinary jurists who have all been drawn to the laws of justice were immersed in abstract philosophy, enough to be moved by the sheer force of argument alone. Helmholz notes that while it can be surmised that founding-era American jurists had some exposure to the work of Grotius, Pufendorf, and other natural law theorists, "the extent of this contact with the law of nature was nothing to brag about. It was almost incidental, not professional." 115 Similarly, Hamburger writes that most English jurists in the 17th century "were

"Eliminativism and the Challenge from Folk Beliefs" (2009) 43:2 Noûs 242, describing the philosophical challenge of explaining folk error.

112. See DM Kovacs, "How to be an Uncompromising Revisionary Ontologist" (2019) 198:3 Synthese 2129.

113. For general discussion, see EH Atiq, "There are No Easy Counterexamples to Legal Antipositivism" (2020) 17:1 Journal of Ethics \& Social Philosophy 1 at 3: "While it would indeed be question begging to assume anti-positivism is refuted by simply pointing to these cases of apparent legality, the problem for the anti-positivist is that it is very hard to explain away (as widespread error) judgments made by a diverse range of experts and nonexperts about law."

114. Thanks to an anonymous reviewer for the suggestion.

115. Helmholz, supra note 30 at 130 . Helmholz concludes that it is "hard to arrive at a fully satisfactory explanation for what the authors of American independence knew" that would account for their broad sympathies towards the idea of unwritten laws of justice. Ibid at 128. 
blissfully ignorant of ponderous natural-law tomes" and yet "non-technical features of natural-law analysis were widely ... received." 116 Philosophical arguments tend to influence ordinary or commonly held beliefs when the arguments justify claims that seem independently intuitive. Consider arguments for the existence of free will. No doubt such arguments have found a receptive audience outside of philosophy. But belief in free will, however mistaken, can hardly be explained away as an error transmitted to the many by the sheer force of philosophical argument. Likewise, while jurists committed to the laws of justice may have had incidental exposure to philosophical considerations, they presumably found the existence of such laws independently intuitive. Another way to put it is that the existence of universally valid laws of justice must have been concordant with their concept of law. ${ }^{117}$ Hence, what needs to be explained is why the 'laws of justice' seemed intuitive in this way to a wide range of legal officials.

This is a convenient juncture at which to revisit a possibility raised in our discussion of fictionalism: namely, that the mistaken beliefs may be due to wishful thinking or motivated reasoning. The positivist might be tempted by a just-so story along the following lines:

When jurists encountered cases where the law leads to unjust results, they ignored the (positive) law and decided the case based on moral norms that they wished were law. Sooner or later, they became confused and started supposing that what morality requires is the law, independently of their own agency.

Kunda, in her foundational work on the psychology of motivated reasoning, documents the "considerable evidence that people are more likely to arrive at conclusions that they want to arrive at" but notes that "their ability to do so is constrained by their ability to construct seemingly reasonable justifications for these conclusions." 118 The problem for the positivist's motivated reasoning story is that jurists who treated moral principles as law made no attempt to justify their judgments in social terms. On the contrary, they expressly denied that moral laws are derived from socially embraced rules or dependent on custom. ${ }^{119}$ Their legal intuitions seem insensitive to what, according to positivism, determines whether a rule is law or not—-social facts. In other words, juridical reasoning concerning the

116. Hamburger, supra note 48 at 2093. See also JGA Pocock, Politics, Language and Time: Essays on Political Thought and History (University of Chicago Press, 1971) at 5-6, 25-27, 144.

117. Recent experimental work on the 'folk' concept of law finds support for the 'moral law' intuition among 218 undergraduates who had not yet taken any courses in legal philosophy. See B Flanagan \& IR Hannikainen, "The Folk Concept of Law: Law is Intrinsically Moral" (2022) 100:1 Australasian Journal of Philosophy 165. Flanagan \& Hannikainen surveyed students on the legality of immoral laws, and report verdicts consistent with what they describe as a 'natural law' concept of law: "consistently with a natural law view, the more that participants believed the marriage ban to be wrong, the more likely they were to deny that it was truly law ... Studies 1 and 2 demonstrated that people tend to deny the lawfulness of gravely immoral statutes, as predicted by natural law theorists."Ibid at 172,174. In fact, asked outright, "a large majority $(64.4 \%)$ rejected the view that, ultimately, law is just a matter of concrete social facts." Ibid at 175 .

118. Z Kunda, "The Case for Motivated Reasoning" (1990) 108:3 Psychological Bulletin 480 at 480 .

119. See $\S 1$. 
laws of justice does not conform to the recognizable structure of motivated reasoning, at least if we assume a positivist framework for law. ${ }^{120}$

Ultimately, the problem for the error theory can be summarized as follows. The affirmative claims that make up positivism as a theory of law hamstring the error theorist's ability to explain why jurists would consistently and so pervasively make the specific error of thinking, on seemingly intuitive or a priori grounds, that moral principles are a form of law. If a rule's legality is predicated on its being suitably obeyed or derived from more fundamental rules that attract obedience, this renders puzzling why judges would have embraced moral principles as law while explicitly denying that their legality depends on contingent social facts like obedience. Note that the argument of this section is entirely consistent with jurists being mistaken about the legality of moral principles. The target has not been error-theoretic accounts generally, but an error theory that is based on positivism, which, I've argued, lacks a plausible theory of error. Positivism sheds no light on why legal experts ended up confused in the precise way the error theorist portrays them as having been - in particular, why the good and the right appeared to these judges in the guise of legality. And a general theory of law should avoid attributing an arbitrary-seeming error to a broad range of jurists, even ones temporally distant from us.

\section{The Implications of Conceptual Change}

The explanatory strategies considered so far for reconciling the legal historical facts with positivism seem weak. Conventionalists interpret juristic appeals to the laws of justice as based on local customs, contradicting the explicit commentary of jurists. Fictionalists attribute deceit based on a sweeping and undermotivated generalization. Error theorists charge a wide range of legal officials with an unexplained and arbitrary-seeming error. All three approaches assume that there has been no substantial shift in the meaning of legal terminology over time; and perhaps the problem lies with this assumption. An alternative explanatory strategy involves conceding that the term 'law' (or 'lex' or ' $j u s$ ') was used historically with a different intension, while maintaining that law in the modern sense is correctly analyzed in positivistic terms. After all, the concepts that attach to our words are arguably fixed by the dispositions of language users, and when those dispositions change (as they plausibly did in the case of 'law'), so do the concepts

120. Leiter points out that judges often take inconsistent positions across cases and suggests that "the jurists may simply be motivated subconsciously by their moral view of the merits, such that they convince themselves of the legal propriety of their preferred outcome." Leiter, supra note 102 at 1247 . Leiter is surely right. This sort of thing happens all the time. The problem facing the motivated reasoning story in the present context, however, is that the judges in question made no effort to rationalize the existence of moral laws in terms of what positivists claim are the true grounds of legality. By contrast, judges usually do try to rationalize inconsistent legal positions based on precedent and the like, just as Kunda suggests about motivated reasoning generally. 
expressed. ${ }^{121}$ It would be consistent with positivism's truth that legal terminology once expressed a concept with robust moral content-call it $\mathrm{LAW}_{\mathrm{OLDE}}$.

The proposal has several virtues. The general phenomenon of conceptual evolution (or referential change) is independently well-motivated. ${ }^{122}$ And the resulting explanation of the historical facts does not involve ignoring juridical commentary on the 'laws' of justice. Nor does it involve attributing arbitrary legal intuitions to legal experts; it may well have been a conceptual truth about $\mathrm{LAW}_{\mathrm{OLDE}}$ that basic principles of fairness fall under the concept. For these reasons, REFERENCE-SHIFT - the view that the meaning of legal terminology has shifted over time-seems to me to be the most plausible approach for the positivist to take if, as the evidence suggests, moral principles were widely described using juridical vocabulary. And there are occasional hints (though only hints) in familiar positivist texts that the target of analysis may be a uniquely modern concept of law. ${ }^{123}$

While this strategy does seem like the best option for the positivist, it is not without cost. Most saliently, positivism's truth seems parochial in a way that requires reconceptualizing the philosophical dialectic. If legal terminology has shifted in meaning, it would be a mistake to construe contemporary legal philosophers as analyzing a subject they share with their historical counterparts. The account of the referent of 'law' (or 'nomos' or 'jus') offered by Aristotle, Aquinas, Grotius, or Pufendorf may well have been appropriate for its time, just as Hart's might be today. This is far from the standard picture of how legal philosophy has progressed.

Furthermore, positivists have some work to do in fleshing out the details of the view. We need an account of conceptual transition-or how the juristic term 'law' came to refer to a subject amenable to positivistic analysis when it originally expressed a concept analytically tied to morality. Since my aim in this paper is not to defend positivism, I leave further development of the view to positivists. It is worth noting, however, that certain ways of filling out the details will entail new theoretical challenges. Consider the fact that legal terminology serves important functions, including a coordinating function in circumstances of disagreement. ${ }^{124}$ LAW $_{\text {OLDE }}$ may well have been a more useful concept for communities to glom on to in search of regulative norms than LAW $_{\text {POSITIVE }}$ in the early days of legal systems, when there was not much codified or customary law to rely

121. On usage facts determining meaning facts, see Horwich, supra note 2; Schroeter \& Schroeter, supra note 2.

122. See generally J Glasgow, "Conceptual Revolution” in Shifting Concepts: The Philosophy and Psychology of Conceptual Variability (Oxford University Press, 2020); JP Burgess, "Madagascar Revisited" (2014) 74:2 Analysis 195.

123. Hart in his postscript describes "the salient features of a modern municipal legal system" as the "starting-point" for his project; see Hart, supra note 4 at 240 [emphasis added]. Raz observes in passing that past cultures may have had a different concept of law, but does not comment on how it was different (let alone that the concept might have been non-positivist in nature) or its significance for the modern conception; see J Raz, "Can There be a Theory of Law" in Martin Golding \& William Edmundson, eds, Blackwell Guide to Philosophy of Law and Legal Theory (Blackwell, 2004) 328. Thanks to Hillary Nye for the point.

124. See generally J Raz, "Authority, Law and Morality" (1985) 68:3 The Monist 295 at 299. 
on. A concept defined partly in terms of a priori moral principles might have granted greater (and necessary) flexibility to legal decision-makers. One might imagine that over time, as the less controversial principles became codified or absorbed into custom, well-organized communities became more concerned with restraining jurists from deviating from time-honored principles than with filling gaps in positive law. In other words, it seems plausible that the dispositions of legal language users changed as their priorities shifted in ways that might explain the transition from $\mathrm{LAW}_{\mathrm{OLDE}}$ to $\mathrm{LAW}_{\mathrm{POSITIVE}}$. Indeed, something like this account has recently been proposed as an explanation for the decline of natural law reasoning in American jurisprudence. ${ }^{125}$

While plausible, an account along these lines invariably draws attention to the possibility that our contemporary concept of law may not be completely denuded of moral content. For even if dispositions to use legal terminology tend towards a positivist-friendly concept as legal systems become increasingly sophisticated, a tendency is hardly a fait accompli. In fact, some of the evidence anti-positivists have traditionally offered against positivism may be reconceived as evidence suggesting that our contemporary concept of juridical law retains moral traces of $\mathrm{LAW}_{\text {OLDE }}$. Put differently, the above account of semantic change may turn out to be more grist for the anti-positivist mill.

As an illustration, we can revisit Dworkin's objection to positivism based on adjudicative reliance on moral principles. When determining the enforceability of a contract, a modern judge might refuse to enforce the contract or a contractual provision on the basis that courts cannot be "used as instruments of inequity and injustice." 126 So, the argument goes (roughly), positivism seems false: facts concerning what the law is are partly determined by moral facts-what is just and fair-independently of the social facts concerning what we do around here. ${ }^{127}$ We have already discussed well-known positivist replies to Dworkin's challenge. These include that mere reliance on a moral principle in adjudication does not establish its legality, and that judges may be treating the principles as law on purely social grounds. Whether these responses ultimately succeed is not presently at issue. The limited point for present purposes is that the possibility of REFERENCE-SHIFT arms anti-positivists with new resources for defending their interpretation of the behavior of modern judges. The anti-positivist can invoke conceptual history - a history that a positivist committed to REFERENCE-SHIFT largely concedes - in defense of the view that contemporary judges are implicitly treating moral principles as law and on purely moral grounds. After all, our legal forebears employed a concept that empowered them not just to rely on moral principles in adjudication but to expressly refer to those principles as, for example, 'the laws of England.' It seems reasonable to assume that this history influences contemporary adjudication, especially if modern judges are disposed to

125. See Banner, supra note 56. Banner argues that an expansion in case reporting and precedential law crowded out natural law in American jurisprudence.

126. Dworkin, "Model of Rules", supra note 5 at 24 . See discussion in $\S 2$.

127. For further discussion, see supra note 86 and accompanying text. 
defer to prior jurists on whether and why moral principles count as law. ${ }^{128}$ If these deference dispositions hold (a big 'if,' to be sure), a modern judge might view the legal status of moral principles as overdetermined-precedential (these days) as well as morally based. A classic Dworkinian observation can thus be seen in a new and potentially more favorable light: as evidence that the traditional conception of law as essentially tied to morality continues to impact contemporary legal practice.

Admittedly, these final observations are speculative, and the use of conceptual genealogy to defend some legal theory (anti-positivist or otherwise) is not the point of this paper. Among other things, an affirmative case would require a more comprehensive examination of the historical record-in particular, how widely jurists classified moral principles as 'law' on a priori grounds. An affirmative case would also involve weighing the virtues of competing accounts of how the legal concept might have changed over time, accounts that neither positivists nor anti-positivists have so far developed. And, ultimately, whether a theory of law is diachronically plausible is just one consideration among many to be weighed in evaluating competing theories. Nevertheless, we have made progress by demonstrating that (a) the history of juridical commentary on the laws of justice warrants greater and more systematic attention than the philosophy of law has traditionally paid it; (b) positivists struggle to explain this history without invoking a theory of conceptual change; and (c) regardless of which side of the Hart-Dworkin debate one favors, a meta-semantics for legal terminology that accommodates conceptual change supplies reasons for revisiting central questions in this debate.

Acknowledgments: A special thanks to Rachel Schutz, Andrei Marmor, David Enoch, Nicole Giannella, and Michael Dorf for their detailed feedback. I presented earlier drafts of the paper at various venues in 2021, including at the University of Chicago Law \& Philosophy Workshop, the University of Surrey Center for Law \& Philosophy, Cornell University Faculty Workshop, Jagiellonian University APLT conference, and the Maastricht Law \& Philosophy seminar. The final version of the paper reflects the thoughtful questions and comments I received from Brian Leiter, Martha Nussbaum, Matthew Etchemendy, Kevin Toh, Ryan Doerfler, Richard Helmholz, Ken Ehrenberg, Lucas Miotto, Alex Sarch, Emily Sherwin, Daniel Peixoto Murata, Marie Newhouse, Bebhinn Donnelly-Lazarov, Simon Palmer, Ambrose Lee, Jeff Rachlinski, Sam Preston, Bill Watson, Danielle Limbaugh, Alison Shea, and Hillary Nye, among others. Sheetal Misra, Ramsha Khursheed, and Tala Brewster provided excellent research assistance

Emad H. Atiq is an Associate Professor of Law at Cornell Law School and an Assistant Professor of Philosophy at the Sage School of Philosophy at Cornell University. His research focuses on the nature of normative reasoning, and the connections between legal, moral, and epistemic norms. Web: http://emadatiq.net. Email: eha47@cornell.edu.

128. On semantic deference and its role in reference-fixing, see e.g. Schroeter \& Schroeter, supra note 2 . 